Journal of Animal and Veterinary Advances $10(6): 728-732,2011$

ISSN: $1680-5593$

(C) Medwell Journals, 2011

\title{
Seasonal Variation of Phytoplankton Composition in a Medium-Size River: The Kirmir and its Tributaries Ankara, Turkey
}

\author{
${ }^{1} \mathrm{O}$. Zencir, ${ }^{2} \mathrm{O}$. Fakioglu, ${ }^{2}$ N. Demir and ${ }^{2}$ A.S. Korkmaz \\ ${ }^{1}$ Kemah Vocational Training School, Erzincan University, Kemah, Erzincan, Turkey \\ ${ }^{2}$ Department of Fisheries and Aquaculture Diskapi, Faculty of Agriculture, \\ Ankara University, Ankara, Turkey
}

\begin{abstract}
The aim of this study was to determine the seasonal variation of phytoplankton in a connected river system, the Kirmir and its tributaries the Suveri and the Ilhan. The samples were collected from a total of ten selected stations on the main river and tributaries in November 2006, February, May and August 2007. A total of 57 phytoplankton species from Bacillariophyta, Chlorophyta, Chrysophyta, Cryptophyta, Cyanobacteria, Euglenophyta and Pyrrophyta were identified. Bacillariophyta species were dominant in all stations during the research period. Caloneis bacillum, Cocconeis placentula, Cyclotella meneghiniana, Diatoma vulgare, Gomphonema ventricosum, Nitzschia sigmoidea and Ulnaria ulna appeared at high densities in the samples. The maximum phytoplankton abundance was found in the Kirmir on all sampling dates. Furthermore, some species which are indicators of pollution were found in the Kirmir.
\end{abstract}

Key words: Phytoplankton, Kirmir river, seasonal succession, species composition, cyanobacteria, pyrrophyta

\section{INTRODUCTION}

Rivers are dynamic systems which are in a constant state of change and they are affected more by changes in their basins than are lakes. Pollution can completely change the organism composition but recovery is faster than in lentic waters. The velocity of the current affects the community structure in rivers.

Research on the hydroecology of river phytoplankton has shown that water residence time, the canal structure of the river, the formation of dead zones, the velocity of discharge and the canal length affect phytoplankton concentration (Soballe and Kimmel, 1987; Allan, 1995; Reynolds, 2000).

Increases in nutrients cause an increase in epiphtytic or benthic algae in fast flowing rivers whereas phytoplankton are dominant in slow flowing rivers (Hilton et al., 2006). Phytoplankton develop in the lower stretches of medium and small rivers when the current becomes slow (Sabater, 1990).

There are many studies of the epiphytic, epilithic, benthic algae and phytoplankton of the rivers of Turkey (Altuner and Gurbuz, 1989; Cevik et al., 1994; Pabuccu and Altuner, 1998; Soylu and Gonulol, 2003). Diatoms and other groups of algae in the Kirmir river have also been identified in 1996-1997.
Organic pollution from agriculture has been reported in the Kirmir river which is one of the important tributaries of the Sakarya river. The Kirmir river has been used for irrigation and is classed as a medium size river with a length of $130 \mathrm{~km}$ and an average flow rate of $3.38 \mathrm{~L} \mathrm{sec}^{-1}$ (Atalay, 1994).

The aims of the present study were to provide a description of the species composition of the phytoplankton and to determine its seasonal changes in the Kirmir river and its tributaries.

\section{MATERIALS AND METHODS}

This study was carried out in the Kirmir river and its tributaries the Suveri and the Ilhan in the Sakarya river basin. The Kirmir river is located in the northwestern part of the Central Anatolian region of Turkey at $40-41^{\circ} \mathrm{N}$ and $32-33^{\circ} \mathrm{E}$ and its basin lies within the boundaries of Ankara province (Kucuk, 2008) (Fig. 1). The water samples were collected from 10 stations (4 stations from the Kirmir river, 3 stations from the Ilhan river and 3 stations from the Suveri river) in November 2006, February, May and August 2007 (Fig. 2). The water temperature, flow velocity, dissolved oxygen, $\mathrm{pH}$ and conductivity were also measured in situ (Table 1).

Water samples were collected from below the surface in $250 \mathrm{~mL}$ bottles. The samples were fixed using Lugol's iodine. Phytoplankton counts were made using 10-100 mL

Corresponding Author: O. Zencir, Kemah Vocational Training School, Erzincan University, Kemah, Erzincan, Turkey 


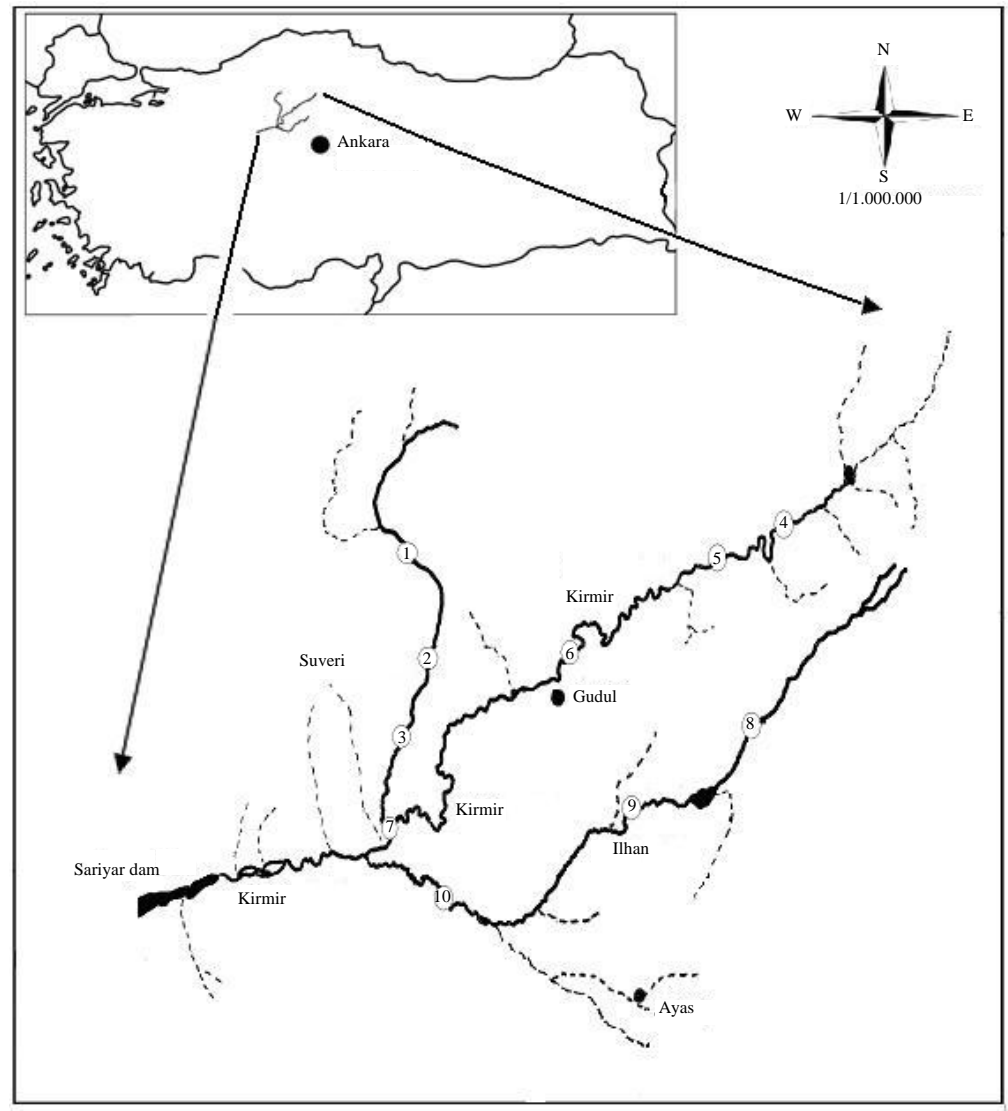

Fig. 1: Location and the sampling stations of the Kirmir river and its tributaries

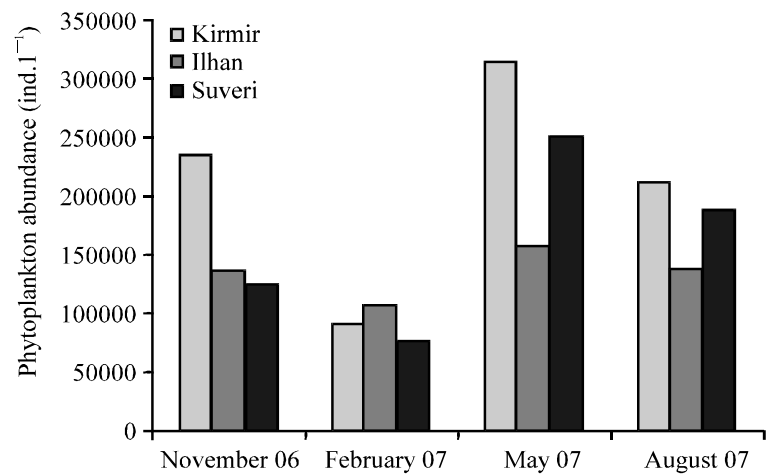

Fig. 2: The changes of phytoplankton abundance in November 2006 and February, May and August 2007 in the Kirmir river and its tributaries

Table 1: Minimum and maximum values of various physico-chemical parameters in the study period, measured in the Kirmir river and its tributaries

\begin{tabular}{llll}
\hline \multicolumn{1}{c}{ Parameters } & Kirmir & Ilhan & Suveri \\
\hline pH & $7.03-8.24$ & $7.38-8.65$ & $7.17-8.45$ \\
Dissolved oxygen $\left(\mathrm{mg} \mathrm{L}^{-1}\right)$ & $7.3-11.5$ & $7.4-10.3$ & $7.8-10.5$ \\
Water temperature $\left({ }^{\circ} \mathrm{C}\right)$ & $5-25$ & $5.5-22.5$ & $6-24$ \\
EC $\left(\mu\right.$ mhos $\left.\mathrm{cm}^{-1}\right)$ & $1200-1966$ & $1025-1939$ & $1165-1986$ \\
Flow velocity $\left(\mathrm{m} \mathrm{sec}^{-1}\right)$ & $0.21-0.71$ & $0.13-0.56$ & $0.18-0.45$ \\
\hline
\end{tabular}

settling chambers with an inverted microscope by the Utermohl method. Phytoplankton was identified by binocular microscope and diatoms were identified after cleaning with a sulphuric and nitric acid mixture. The common taxonomic literatures were used (Cox, 1996; John et al., 2002).

\section{RESULTS AND DISCUSSION}

A total of 58 phytoplankton species from Bacillariophyta, Chlorophyta, Chrysophyta, Cryptophyta, Cyanobacteria, Euglenophyta and Pyrrophyta were identified in the Kirmir river and its tributaries (Table 2).

Pyrrophyta was not present in the Kirmir river while Peridinium sp. were found in high concentrations in the Ilhan river. There were no records of Chrysophyta, Cyanobacteria, Cryptophyta and Euglenophyta species in the Ilhan river or of Cryptophyta, Cyanobacteria, Euglenophyta and Pyrrophyta in the Suveri river. The highest number of species in the study period was determined in the Kirmir followed by the Ilhan and the Suveri. The diversity of pennate diatoms was found to be 
Table 2: Phytoplankton species identified and their abundance from the Kirmir river and its tributaries*

\begin{tabular}{|c|c|c|c|c|}
\hline \multirow{42}{*}{$\frac{\text { Phylum }}{\mathrm{BA}^{* * *}}$} & Species & Kirmir river & Ilhan river & Suveri river \\
\hline & Amphora ovalis (Kutzing) Kutzing & ++ & + & ++ \\
\hline & A. pediculus (Kutzing) Grunow ex A. Schmidt & ++ & + & ++ \\
\hline & Anomoeone is follis (Ehrenberg) Cleve & ++ & + & ++ \\
\hline & Aulocoseira granulata (Ehrenberg) Simonsen & ++ & + & ++ \\
\hline & Melosira moniliformis (O.F. Muller) C. Agardh & ++ & + & ++ \\
\hline & Caloneis bacillum (Grun.) Mereschkowky & +++ & ++ & ++ \\
\hline & Cocconeis placentula Ehrenberg & +++ & ++ & +++ \\
\hline & Craticula cuspidata (Kutzing) D.G. Mann & ++ & + & + \\
\hline & Cyclotella meneghiniana Kutzing & +++ & ++ & +++ \\
\hline & C. ocellata Pandocsek & ++ & + & ++ \\
\hline & Cymbella affinis Kutzing & +++ & ++ & +++ \\
\hline & C. cistula (Hemprich and Ehrenberg) O. Kirchner & ++ & + & ++ \\
\hline & C. cymbiformis C. Agardh & ++ & + & ++ \\
\hline & C. tumida (Brebisson in Kützing) van Heurck & ++ & + & ++ \\
\hline & Cymatopleura solea $\mathrm{W}$. Smith & + & + & ++ \\
\hline & Diadesmis perpusilla (Grunow) D.G.Mann & + & + & ++ \\
\hline & Diatoma vulgare Bory de Saint-Vincent & +++ & ++ & +++ \\
\hline & Didymosphenia geminata (Lyng.) M. Schmidt & - & - & ++ \\
\hline & Epithemia argus (Ehrenberg) Kutzing & ++ & + & + \\
\hline & E. muelleri Fricke & + & + & ++ \\
\hline & Fragilaria copucina Desmazieres & ++ & + & + \\
\hline & F. virescens Ralfs & + & + & + \\
\hline & Gomphonema acuminatum Ehrenberg & + & + & ++ \\
\hline & G. angustotum (Kutzing) Rabh. & ++ & + & ++ \\
\hline & G. olivace um (Hornemann) Kutzing & ++ & + & ++ \\
\hline & G. ventricosum Gregory & +++ & ++ & ++ \\
\hline & Gyrosigma acuminatum (Kutzing) Rabenhorst & ++ & + & ++ \\
\hline & Hantzschia amphioxys (Ehrenberg) Grun. & ++ & + & ++ \\
\hline & $\begin{array}{l}\text { Hippodonta capitata (Ehrenberg) Lange-Bertalot, } \\
\text { Metzeltin and Witkowski }\end{array}$ & + & + & - \\
\hline & Nitzschia gandersheimiensis Krasske & + & - & ++ \\
\hline & N. linearis (C.Agardh) W. Smith & - & - & + \\
\hline & N. recta Hantzsch & ++ & + & + \\
\hline & N. sigmoidea (Ehr.) W. Smith & +++ & + & +++ \\
\hline & N. thermalis Kutzing & ++ & + & ++ \\
\hline & Pinnularia appendiculata (Agardh) Cleve & + & + & ++ \\
\hline & P. viridis (Nitzsch) Ehrenberg & ++ & + & - \\
\hline & Rhoicosphenia curvata (Kutz.) Grun. ex Rabenhorst & + & + & ++ \\
\hline & Rhopalodia gibba (Ehrenberg) O.F. Muller & ++ & + & ++ \\
\hline & Suriella ovalis Brebisson & ++ & + & + \\
\hline & Ulnoria capitata (Ehrenberg) P. Compere & ++ & + & ++ \\
\hline & U. ulna (Nitzsch) P.Compère & +++ & + & + \\
\hline \multirow[t]{10}{*}{$\mathrm{CHL}$} & Closterium moniliferum (Bory) Ehr. ex Ralps & + & + & - \\
\hline & Coelastrum microporum Nageli in A.Braun & + & + & + \\
\hline & Cosmarium sp. & + & + & + \\
\hline & Pediastrum boryanum (Turpin) Meneghini & + & + & - \\
\hline & Scenedesmus arcuatus Lemmermann & + & + & ++ \\
\hline & S. bijuga var. disciformis (Chodat) C.R. Leite & ++ & + & - \\
\hline & S. ellipticus Corda & + & - & - \\
\hline & S. quadricauda (Turpin) Brebisson & - & + & + \\
\hline & Spirogyra sp. & + & + & + \\
\hline & Tetraedron couddum (Corda) Hansgirg & ++ & - & + \\
\hline $\mathrm{CH}$ & Dinobryon divergens O.E. Imhof & + & - & + \\
\hline CR & Rhodomonas lacustris var. nannoplanctica (Skuja) Javomicky & ++ & - & - \\
\hline $\mathrm{CY}$ & Chroococcus minitus (Kutzing) Naegeli & ++ & + & - \\
\hline EU & Euglena acus Ehrenberg & + & - & - \\
\hline \multirow[t]{2}{*}{ PYR } & Peridinium bipes $\mathrm{F}$. Stein & - & +++ & - \\
\hline & P. cinctum (O.F. Muller) Ehrenberg & - & +++ & - \\
\hline
\end{tabular}
Bacillariophyta, CHL: Chlorophyta, CH: Chrysophyta, CR: Cryptophyta, CY: Cyanobacteria, EU: Euglenophyta, PYR: Pyrrophyta

high while centric diatoms were represented by four species. Pennate diatoms, Caloneis bacillum, Cocconeis placentula, Cyclotella meneghiniana, Diatoma vulgare, Gomphonema ventricosum, Nitzschia sigmoidea and Ulnaria ulna were observed at high concentrations. The epipelic, epiphytic, epilithic and planktonic algae of the
Kirmir river were investigated in two parallel studies and Navicula, Cymbella and Nitzschia sp. constituted $46 \%$ of the total number of species between 1996 and 1997. The higher number of phytoplankton species in the Kirmir river may be explained by the development of a phytoplankton community with increased river size. It has 


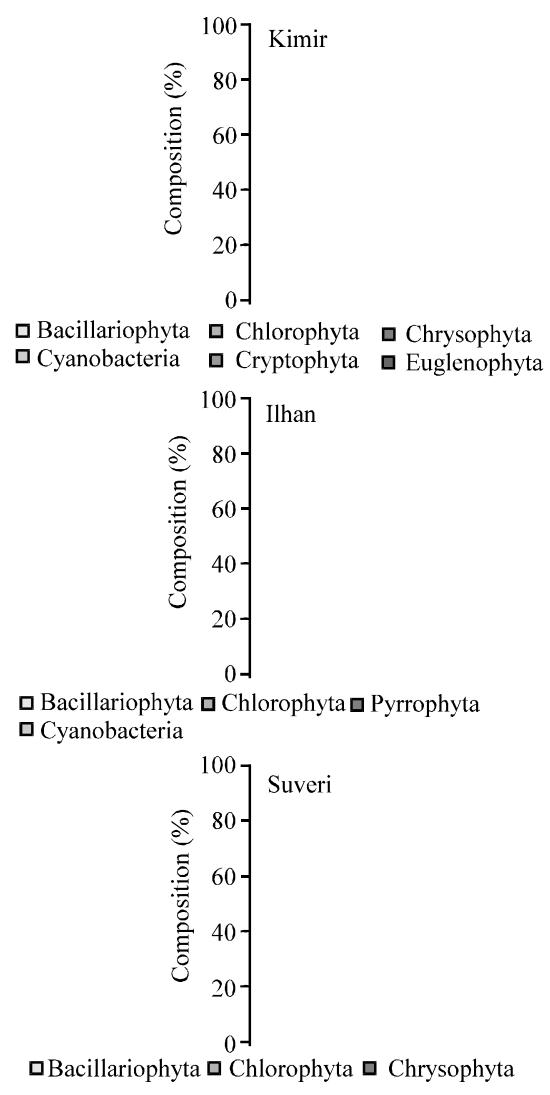

Fig. 3: Changes in phytoplankton composition (\%) in November 2006, February, May and August 2007 in the Kirmir river and its tributaries

been reported that river size and flow velocity is crucial in the development of phytoplankton in rivers. True river plankton occurs in larger rivers (third-order streams and greater) throughout the world (Reynolds, 2000). Didymosphenia geminata was found to be intense in spring in the Suveri river. It was reported that this species may occur on the substratum where wastewater effluents mix (Kelly, 2000). There are meadows around the Suveri river and an organic enrichment was observed.

Cyclotella sp. of centric diatoms were found at high concentrations in the Kirmir river. Diatoms, usually species of centric genera (Stephanodiscus and Cyclotella) were relatively abundant in most of the rivers examined by Reynolds (2000).

During the study period, the proportion of Bacillariophyta was $81 \%$ in the Kirmir river, $84 \%$ in the Ilhan river and $90 \%$ in the Suveri river (Fig. 3). The ratios of green algae within the total potamoplankton in the Kirmir, Ilhan and Suveri rivers were 9, 5 and $7 \%$, respectively. The genera represented in the phytoplankton were mostly diatoms and small green algae that are typically able to maintain fast rates of growth
(Reynolds, 2000). It has been reported that Bacillariophyta dominated in the rivers of Turkey (Soylu and Gonulol, 2003). In Turkish rivers, centric diatoms have generally been found more frequently than pennads (Yildiz, 1984; Soylu and Gonulol, 2003; Kalyoncu et al., 2004). On the other hand, Sabater (1990) reported that in the rivers of Europe, the density of pennad diatoms was high. In the present study, it was found that the number of centric diatoms was high in the Kirmir river whereas the number of pennads was high in its tributaries.

Blue-green algae did not exceed 3\% of total phytoplankton in the Kirmir and Ilhan rivers and they were not recorded in the Suveri. Euglena acus was recorded in November May and August in the Kirmir river. Peridinium bipes and $P$. cinctum from the Pyrrophyta reached a significantly high abundance level in the Ilhan river.

This genus has not been previously reported from Turkish rivers. The species might have been inoculated from a pond on the Ilhan river because this species was not found from the upstream sampling station (station 8) on the Ilhan river.

In this study, Euglena acus was identified at the stations on the Kirmir river. Euglenophyta members were identified in the Meram Stream (Yildiz, 1984), the River Karasu (Altuner and Gurbuz, 1989) and the Aksu Stream (Ertan and Morkoyunlu, 1998). Euglenophyta species are indicators of eutrophication. The appearance of this species indicated eutrophy.

\section{CONCLUSION}

In the Kirmir river and its tributaries, most of the phytoplankton was found to be of epilithic-epiphytic species. Their diversity and abundance varied depending on the seasons. Long-term monitoring programs are needed due to the irrigational and recreational use of this river system.

\section{REFERENCES}

Allan, J.D., 1995. Stream Ecology: Structure and Function of Running Waters. Kluwer Academic Publishers, Dordrecht, Netherlands.

Altuner, Z. and H. Gurbuz, 1989. Study on the phytoplankton community of Karasu (Firat) River. Inonu Univ. J. Aquacult, 3: 151-176.

Atalay, I., 1994. Geography of Turkey. Ege University Press, Izmir.

Cevik, F., M.L. Goksu and E. Sarihan, 1994. Planktonic algae and seasonal variation of Seyhan River (Adana), (in Turkish). Proceedings of the 12th National Biology Conference, July 6-8, Edirne, Turkey. 
Cox, E.J., 1996. Identification of Freshwater Diatoms from Live Material. 1st Edn., Chapman and Hall, London, pp: 158.

Ertan, O.O. and A. Morkoyunlu, 1998. The algae flora of aksu stream (Isparta-Turkey). Turk. J. Bot., 22: $239-255$.

Hilton, J., M. O'Hare, M.J. Bowes and J.I. Jones, 2006. How green is my river: A new paradigm in eutrophication in rivers. Sci. Total Environ., 365: 66-83.

John, D.M., B.A. Whitton and A.J. Brook, 2002. The Freshwater Algal Flora of the British Isles. Cambridge University Press, UK.

Kalyoncu, H., M. Barlas, O.O. Ertan and H. Gulboy, 2004. Determination of water quality of Aglasun stream according to physicochemical parameters and ephilithic algae. Egirdir J. Aquacult. Faculty, 2: 7-14.

Kelly, M., 2000. Identification of common benthic diatoms in rivers. Field Stud., 9: 583-700.

Kucuk, S., 2008. The effect of organic pollution on benthic macroinvertabrate fauna in the Kirmir Stream in the Sakarya Basin. ADU J. Agric. Faculty, 5: 5-12.
Pabuccu, K. and Z. Altuner, 1998. Planktonic algal flora of Yesilirmak River (Tokat-Turkey). Bull. Pure Applied Sci., 17: 101-112.

Reynolds, C.S., 2000. Hydroecology of river plankton: The role of variability in channel flow. Hydrological Process., 14: 3119-3132.

Sabater, S., 1990. Phytoplankton composition in a medium-sized Mediterranean River: The Ter (Spain). Limnetica, 6: 47-56.

Soballe, D.M. and B.L. Kimmel, 1987. A large-scale comparison of factors influencing phytoplankton abundance in rivers, lakes and impoundments. Ecology, 68: 1943-1954.

Soylu, E.N. and A. Gonulol, 2003. Phytoplankton and seasonal variations of the River Yesilirmak, Amasya, Turkey. Turk. J. Fish. Aquatic Sci., 3: $17-24$.

Yildiz, K., 1984. Studies on the algae community in the Meram Stream, Algae community on II. Sone and plants. J. Sci., 3: 219-222 (in Turkish). 